\title{
The constitutions of international organisations: How institutional design seeks to foster diplomatic deliberation
}

\author{
D I A N A P A N K E (D) \\ Department of Political Science, Albert Ludwig University of Freiburg, Belfortstrasse 20, \\ 79085 Freiburg, Germany
}

Email: Diana.Panke@politik.uni-freiburg.de

\author{
F R A N Z I S K H O H L S T E I N \\ Department of Political Science, Albert Ludwig University of Freiburg, Belfortstrasse 20, \\ 79085 Freiburg, Germany
}

Email: Franziska.Hohlstein@politik.uni-freiburg.de

G U R U R P O L A T

Department of Political Science, Albert Ludwig University of Freiburg, Belfortstrasse 20, 79085 Freiburg, Germany

Email: Gurur.Polat@politik.uni-freiburg.de

\begin{abstract}
Whether we look at constitutions of states or founding treaties of International Organisations ( $\mathrm{IO})$, it is striking that many rules on interaction between delegates create room for deliberation, whilst simultaneously limiting the time for discussion. While the latter speeds up decision making, it risks reducing its quality and legitimacy by hampering the exchange and contestation of information and ideas. How are these competing elements balanced in IOs? Do IOs differ in this respect, and if so, how and why? The article draws on a unique and novel dataset and assesses variation in the extent to which institutional design fosters or inhibits diplomatic deliberation in more than 110 diverse IOs. To this end, the article uses a combination of theories of functionalism, rational choice institutionalism and liberal approaches on variation, fit, and mismatch of deliberative institutional design within and across IOs. The hypotheses are analysed with quantitative methods. The article shows that diplomatic deliberative institutional design elements are the most pronounced when IOs are small in size, deal in high politics, and are regional in character.
\end{abstract}

Keywords: International Organisation; institutional design; diplomats; deliberation; quantitative analysis 


\section{Introduction}

Especially since the end of WWII, states have created numerous International Organisations $(\mathrm{IO})$, covering a broad array of policy areas and attracting numerous member states. In these institutionalised negotiation arenas, national diplomats create binding or non-binding international rules and norms (Kelsen 1966; Alvarez 2005). To this end, they articulate national positions and exchange legal, factual, normative and political arguments for and against text proposals or changes (Menkel-Meadow 1983; Kratochwil 1989; Beaulac 2004; Koskenniemi 2006; Levi 2013). Diplomatic deliberation, as the exchange and contestation of positions, claims, demands and reasons, is not just a symbolic exercise taking place during the making of international hard or soft law, since the power of the spoken word can influence interaction outcomes, and possibly also the quality, legitimacy and efficiency of governance beyond the nation state (Manin 1987; Fishkin 2002; Cohen 2003; Thompson 2008; Cohen 2012; Wiener 2014).

The institutional design of IOs is spelled out in their primary law, which can encompass founding treaties, treaty changes, annexes and protocols. The body of IO primary law serves as their 'constitution' (Dunoff 2006; Dunoff and Trachtman 2009). Although 'the optimal design of international institutions to confront $21^{\text {st }}$ century challenges is an increasingly urgent question' (Abbott and Gartner 2012), we know very little about how and why institutional designs of IOs differ in facilitating deliberation between state actors and to what effect.

Within the 'deliberative turn', scholars from political science, political philosophy and sociology focused on the phenomenon of deliberation (Hamlin and Pettit 1989; Schneiderhan and Khan 2008; Gutmann and Thompson 2009; Dryzek 2012; Ryfe 2007). While deliberation is broadly understood as the communicative exchange of claims and reasons between actors, different scholars define deliberation in different manners. While some focus on the speech acts exchanged (position or claim backed up by factual, normative, legal, scientific or political reason) (Landwehr and Holzinger 2010), others stress that deliberation is a reflexive process that requires 'reason-giving and listening' (Bächtiger and Parkinson 2019) ${ }^{1}$ and that for deliberation to take place it is essential that actors are open not only to persuade others but also to become persuaded in the wake of the better argument themselves (Habermas 1995a, 1995b). We follow a broad definition of deliberation that makes no ontological assumptions about

1 Mansbridge and Dryzek both make the same point and define deliberation as 'mutual communication that involves weighing and reflecting on preferences, values and interests regarding matters of common concern' (cited from Mansbridge 2015: 27 adapted from Dryzek 2000). 
the actors' degree of reflexivity or the endogeneity of their interests and preferences. Instead, we define deliberation as the exchange and contestation of ideas on the basis of national positions that actors justify with legal, factual, normative, causal, scientific, ethical or values-based reasons. ${ }^{2}$

The 'deliberative turn' gave rise to studies on how deliberative elements within democracies, such as deliberative assemblies or online deliberation, influence the quality, efficiency and legitimacy of governance (Goodin and Dryzek 2006; Shapiro 2003; Goodin 2008). Compared to deliberation within states, we know less about deliberation within IOs. Individual case studies shed light on the usage or arguments by diplomats and study how it translates into negotiation success (Risse 2000; Deitelhoff and Müller 2005; Panke 2010; Reinhard, Biesenbender and Holzinger 2014). Although many scholars point out that institutional design matters and can influence deliberative practices (Habermas 1995a; Joerges and Neyer 1997; Panke 2006; Deitelhoff 2009; Landwehr and Holzinger 2010; Risse and Kleine 2010; Risse 2000; Deitelhoff and Müller 2005; Panke 2010, ; Reinhard, Biesenbender and Holzinger 2014), no one has systematically examined in a comparative manner to which extent and why IO constitutions differ when it comes to inducing diplomatic deliberation. Additionally, no one has studied the extent to which state actors deliberate over a large number of IOs, and their corresponding effects. These gaps are surprising for several reasons. First, IO institutional design essentially regulates how diplomats as the core actors with voting rights interact in order to create negotiation outcomes. For example, rules setting a maximum number of pro and con arguments per proposal or rules restricting the duration of a speaker's time or the discussions in general seek to delimit the extent of diplomatic deliberation and speed up negotiations. At the same time, IO institutional design features, such as provisions allowing for the right of reply or rules on making proposals orally rather than in writing only and do so without secondment, seek to induce diplomatic deliberation as the exchange and contestation of ideas on the basis of national positions and legal, factual, normative, causal, scientific, ethical or values-based reasons.

While diplomatic deliberation reduces the speed of decision-making, deliberation can increase the legitimacy and possibly also the quality of outcomes (Manin 1987; Hamlin and Pettit 1989; Franck 1990; Steffek 2000; Biegoń 2016; Eckl 2017). Diplomatic deliberation can be time-intensive

2 We use this definition since we are interested in the extent to which IO institutional design seeks to induce deliberation between diplomats as creating opportunities for the exchange and challenge of positions complemented by reasons, while we do not examine how exactly diplomats behave in these IOs in practice (i.e. whether reason-giving and listening is indeed taking place) and how and under what conditions persuasion dynamics evolve so that interest and position-changes take place in the wake of a better argument. 
and therefore reduces the effectiveness of decision-making - especially as the IO in question has many member states. At the same time, diplomatic deliberation can bring about a principled and well-justified outcome that reflects not simply the lowest common denominator of the actors' initial positions. IOs have a demand for legitimacy (Grigorescu 2015; Dingwerth et al. 2019), not only since this increases the chances that state actors choose them as arenas under conditions of regime complexity in the first place and use them in order to pursue ambiguous policy goals, but also because this increases state compliance with IO outcomes afterwards (Tallberg and Zürn forthcoming). Since legitimacy is the acceptance of the exercise of authority as appropriate by the governed (Tallberg and Zürn forthcoming), how IOs are institutionally designed can matter (Grigorescu 2015; Lenz and Viola 2017). IOs that are designed to induce high levels of diplomatic deliberation have greater potential to produce high-quality decisions thereby grounding the final IO outcomes in sound argumentation rather than merely reflecting the interest of a few powerful actors. This is important as the perceptions of citizens of an IO's procedural and performance quality impacts its legitimacy (Anderson, Bernauer and Kachi forthcoming).

In fact, many institutional design rules of IOs tend to either foster or restrict diplomatic deliberation, in order to create a balance between the speed of negotiations as well as the legitimacy and/or quality of negotiation outcomes. Yet, we do not know how different IOs balance these competing aims in their institutional designs. Second, several studies have analysed the access of organised civil society actors, such as non-governmental organisations, to decision makers in IOs as well as the deliberative quality effects of civil society access (Bexell, Tallberg and Uhlin 2010; Nanz and Steffek 2004, 2005; Kuyper 2014; Tallberg et al. 2013). While we know a lot about IO institutional design and its openness for non-state actors, we do not know how IOs vary in the extent to which their institutional design facilitates deliberation between the core actors: states. This is all the more surprising as multilateral negotiations within IOs are an essential part of international relations in the twenty-first century, ranging from climate change and other environmental topics to trade and international security.

In order to fill gaps in our current knowledge, this article addresses the following research question: To what extent do IOs incorporate deliberative institutional design features and how can we explain variation in the extent to which institutional design seeks to foster diplomatic deliberation between IOs?

We answer this question in the following steps. Section II introduces the dataset, which captures how strongly IOs are institutionally designed to foster or delimit diplomatic deliberation. We create a diplomatic 
deliberative design index (DDDI) and examine how IOs differ in this respect (Section III). Most notably there is considerable variation between IOs. While some, such as the Conferencia de Autoridades Audiovisuales y Cinematográficas de Iberoamérica (CAACI), the International Office of Epizootics (OIE), and the United Nations Industrial Development Organization (UNIDO) hardly seek to foster deliberation, the Conference of Disarmament (CD), the International Commission for the Protection of Mosel and Saar (IKSMS) and the Central American Integration System (SICA) are located at the other end of the continuum, while IOs such as the Organisation for Economic Co-operation and Development (OECD), the United Nations Security Council (UNSC) or the International Monetary Fund (IMF) are in between. In order to account for this variation, section IV draws on functionalism, rational choice institutionalism and liberal approaches and develops hypotheses. Section V examines the empirical plausibility of the hypotheses based on quantitative methods. This reveals that IOs which focus on high politics issues have institutional designs which are significantly geared towards fostering diplomatic deliberation. In addition, IOs with a regional focus and IOs that are small in size tend to also feature constitutions with features geared towards diplomatic deliberation.

\section{Measuring the diplomatic deliberative quality of IO institutional design}

This section discusses the construction of the dataset starting with the sampling of IOs, followed by the introduction of the selected institutional design criteria, the construction of the deliberative institutional design index and the coding-related decisions.

International Organisations are defined as institutionalised forms of cooperation between three or more states (Hurd 2011). We further specified this definition through the following criteria: First, we only include IOs whose purpose is to create or reinforce international norms and rules, while all IOs that have no authority to engage in such standard-setting activities are excluded (e.g. commercial purpose organisations such as banks, advisory bodies like think tanks, scientific study groups). Second, IOs must be composed of member states and in exceptional cases regional organisations, whereas organisations including firms, private persons etc. are excluded. Third, an IO must still be in operation in 2016 rather than just existing on paper, which we captured by the existence of an updated homepage. The last criterion allows to exclude so-called 'Zombie-IOs' which only exist on paper but are no longer in operation or in use (Gray 2018). The existence of an updated homepage is the prerequisite to access 
and obtain the necessary documentation to comprehensively map IO institutional design (see below). ${ }^{3}$

The basis for the selection of IOs as defined above is the Correlates of War database (Pevehouse, Nordstrom and Warnke 2004) as well as the Yearbook of International Organizations, ${ }^{4}$ because they together cover the universe of IOs, while each database alone omits some cases. ${ }^{5}$ Out of this universe of IOs we selected a representative subsample of 114 IOs, in which states and state-based actors (e.g. the European Union) constitute the members, ${ }^{6}$ which are still in operation in 2016 , have a website, and provide primary law documents and information about rules of procedures. The sample includes IOs that vary with regard to their size, age, policy field, regional vs. global reach and proportional representation of world regions concerning the regional IOs.

For all the IOs included in the sample, we coded their diplomatic deliberative institutional design, which structured the interaction of state actors in the main legislative arena and if present, the respective subsidiary bodies of the IOs. ${ }^{7}$ Our main focus is on the deliberation of state actors in IOs rather than on IO bureaucrats or observers as member states are the constituents of IOs as thus the main actors responsible for dynamics and outcomes of interaction. Yet, since in some IOs non-state actors (NGOs), associates and state or non-state observes can in some instances formally, in others informally also take the floor, we also take them into account when coding the deliberative nature of IO institutional design (see framework conditions below).

For the coding, we used two sources: IO constitutions as primary law (e.g. founding treaties and treaty changes, protocols, annexes) as well as the procedural rules (e.g. terms of references, rules of procedures). For each IO we captured the extent to which their institutional design seeks to induce or hamper diplomatic deliberation for one year. We decided to

3 We opted for the reference year '2016' for research programmatic reasons, since our research project started in 2017.

4 See further <https://uia.org/yearbook>.

5 For instance, the COW does not entail European Association of National Metrology Institutes (EURAMET), while the Yearbook of International Organizations omits the International Civil Defense Organization (ICDO).

6 Thus, we omitted organisations which only or predominantly includes private actors as members, such as the International Coral Reef Initiative (ICRI).

7 We distinguish the main legislative arena from executive bodies, consultative bodies and judicial bodies of IOs. In the main legislative arena, actors discuss and decide upon IO policy outcomes, such as resolutions, regulations, norms and other forms of hard and soft law. Most importantly, the members of the main legislative bodies are state delegates who are responsible to the governments of their respective countries (usually diplomats, sometimes ministers or heads of state or government). 
collect all data for the year 2016 as this is the year for which we were able to systematically gather all treaty documents (founding treaties and subsequent changes) and all rules of procedures. We opted against using the founding year of an IO as reference point since this would not allow to systematically include rules of procedure into the coding and since this would neglect that in some IOs treaty changes took place over time and adjusted the institutional design. Furthermore, coding the IOs for their respective founding years only would make comparisons difficult, as some were created in the aftermath of WWII or even earlier (such as the International Labor Organization (ILO) created in 1919), while others are considerably younger (such as the Union of South American Nations (UNASUR) created in 2008).

Drawing on the literature on deliberation (Bächtiger and Hangartner 2010; Cohen 2003; Deitelhoff 2006; Habermas 1995a; Landwehr and Holzinger 2010), we developed a detailed coding scheme. We differentiate between three stages of IO policy cycles namely agenda setting, negotiation, and final decision-making and identify several elements related to deliberation for each of the stages (for an overview compare Table A1, Appendix). Every element was captured by one or several indicators. The first stage, the agenda-setting stage, starts with the drafting of agenda items and ends with a finalised agenda (Panke 2013). The second stage, the negotiation stage, starts once the actors have a meeting agenda and ends after substantive text changes are finalised. The third stage, the voting stage starts after the main negotiations are concluded and incorporates the debates around and after the formal passing of a negotiation outcome took place (Panke 2013).

In the agenda-setting stage, we distinguish three different elements, namely calling a meeting, right to agenda setting, possibilities to change the agenda. Examples for rules increasing the possibility of diplomatic deliberation in the agenda-setting stage include not limiting the number of speakers allowed to discuss the pros and cons of whether an item should be included on the negotiation agenda and not putting a time limit on the discussion of the agenda. In the negotiation stage, we distinguish between four elements that can facilitate or hinder deliberation between diplomats (dynamics of debate, Chair competences to regulate, making proposals, and interruption of debate). For instance, not limiting the number of times a state may speak up during a debate and provisions to give way, and a right of reply, provisions allowing for speakers to be interrupted by other states, making proposals orally instead of putting them in writing are all conducive to diplomatic deliberation. Examples of rules limiting diplomatic deliberation in the negotiation stage include granting chairs the competence to interrupt speakers and shorten their speeches, requiring secondments for proposals or amendments during negotiations or not allowing or severely limiting 
Table 1. List of IOs

\begin{tabular}{|c|c|c|c|}
\hline abbreviation & long names & abbreviation & long names \\
\hline $\mathrm{AC}$ & Arctic Council & IOC & $\begin{array}{l}\text { Intergovernmental } \\
\text { Oceanographic } \\
\text { Commission }\end{array}$ \\
\hline ACS & $\begin{array}{c}\text { Association of } \\
\text { Caribbean States }\end{array}$ & IOM & $\begin{array}{c}\text { International Organization } \\
\text { for Migration }\end{array}$ \\
\hline ACTO & $\begin{array}{c}\text { Amazon Cooperation } \\
\text { Treaty }\end{array}$ & IOOC & $\begin{array}{l}\text { International Olive Oil } \\
\text { Council }\end{array}$ \\
\hline AFRICARICE & Africa Rice Center & IORA & $\begin{array}{l}\text { Indian Ocean Rim } \\
\text { Association }\end{array}$ \\
\hline $\mathrm{AL}$ & Arab League & ISA & $\begin{array}{c}\text { International Seabed } \\
\text { Authority }\end{array}$ \\
\hline ALADI & $\begin{array}{l}\text { Latin American } \\
\text { Integration } \\
\text { Association }\end{array}$ & ITSO & $\begin{array}{c}\text { International } \\
\text { Telecommunications } \\
\text { Satellite Organization }\end{array}$ \\
\hline ANRPC & $\begin{array}{c}\text { Association of Natural } \\
\text { Rubber Producing } \\
\text { Countries }\end{array}$ & ITTO & $\begin{array}{l}\text { International Tropical } \\
\text { Timber Organization }\end{array}$ \\
\hline APT & $\begin{array}{l}\text { Asia-Pacific } \\
\text { Telecommunity }\end{array}$ & ITU & $\begin{array}{c}\text { International } \\
\text { Telecommunications } \\
\text { Union }\end{array}$ \\
\hline ARIPO & $\begin{array}{c}\text { African Regional } \\
\text { Intellectual Property } \\
\text { Organization }\end{array}$ & IWC & $\begin{array}{l}\text { International Whaling } \\
\text { Convention }\end{array}$ \\
\hline AU & African Union & MRC & Mekong River Commission \\
\hline BENELUX & Benelux Cooperation & NAFO & $\begin{array}{c}\text { Northwest Atlantic Fisheries } \\
\text { Organization }\end{array}$ \\
\hline BIPM & $\begin{array}{l}\text { International Bureau of } \\
\text { Weights and Measures }\end{array}$ & NASCO & $\begin{array}{c}\text { North Atlantic Salmon } \\
\text { Conservation } \\
\text { Organization }\end{array}$ \\
\hline BSEC & $\begin{array}{l}\text { Black Sea Economic } \\
\text { Cooperation }\end{array}$ & NC & Nordic Council \\
\hline CAACI & $\begin{array}{l}\text { Conferencia de } \\
\text { Autoridades } \\
\text { Audiovisuales y } \\
\text { Cinematográficas } \\
\text { de Iberoamérica }\end{array}$ & NEAFC & $\begin{array}{l}\text { North-East Atlantic } \\
\text { Fisheries Commission }\end{array}$ \\
\hline CABI & $\begin{array}{l}\text { Centre for Agriculture } \\
\text { and Biosciences } \\
\text { Inernational }\end{array}$ & NPFC & $\begin{array}{l}\text { North Pacific Fisheries } \\
\text { Commission }\end{array}$ \\
\hline CAN & Comunidad Andina & OAPEC & $\begin{array}{c}\text { Organization of Arab } \\
\text { Petroleum Exporting } \\
\text { Countries }\end{array}$ \\
\hline CARICOM & Caribbean Community & OAS & $\begin{array}{c}\text { Organization of American } \\
\text { States }\end{array}$ \\
\hline
\end{tabular}


Table 1. (Continued)

\begin{tabular}{|c|c|c|c|}
\hline abbreviation & long names & abbreviation & long names \\
\hline CCNR & $\begin{array}{l}\text { Central Commission for } \\
\text { Rhine Navigation }\end{array}$ & OECD & $\begin{array}{c}\text { Organisation for Economic } \\
\text { Co-operation and } \\
\text { Development }\end{array}$ \\
\hline $\mathrm{CD}$ & $\begin{array}{l}\text { Conference of } \\
\text { Disarmament }\end{array}$ & OEI & $\begin{array}{l}\text { Organization of Ibero- } \\
\text { American States for } \\
\text { Education, Science and } \\
\text { Culture }\end{array}$ \\
\hline CEFTA & $\begin{array}{c}\text { Central European Free } \\
\text { Trade Agreement }\end{array}$ & OIC & $\begin{array}{c}\text { Organization of Islamic } \\
\text { Cooperation }\end{array}$ \\
\hline CENSAD & $\begin{array}{l}\text { Community of Sahel- } \\
\text { Saharan States }\end{array}$ & OIE & $\begin{array}{c}\text { International Office of } \\
\text { Epizootics }\end{array}$ \\
\hline CERN & $\begin{array}{l}\text { European Organization } \\
\text { for Nuclear Research }\end{array}$ & OIF & $\begin{array}{c}\text { Organisation Internationale } \\
\text { de la Francophonie }\end{array}$ \\
\hline CLAC & $\begin{array}{l}\text { Latin American } \\
\text { Commission for } \\
\text { Civil Aviation }\end{array}$ & OIV & $\begin{array}{c}\text { International Vine and Wine } \\
\text { Office }\end{array}$ \\
\hline $\mathrm{COE}$ & Council of Europe & OLADE & $\begin{array}{c}\text { Latin American Energy } \\
\text { Organization }\end{array}$ \\
\hline COSAVE & $\begin{array}{l}\text { Comité Regional de } \\
\text { Sanidad Vegetal del } \\
\text { Cono Sur }\end{array}$ & OPANAL & $\begin{array}{c}\text { Agency for the Prohibition } \\
\text { of Nuclear Weapons in } \\
\text { Latin America }\end{array}$ \\
\hline DANUBE & Danube Commission & OPCW & $\begin{array}{c}\text { Organisation for the } \\
\text { Prohibition of Chemical } \\
\text { Weapons }\end{array}$ \\
\hline EAEU & $\begin{array}{c}\text { Eurasian Economic } \\
\text { Union }\end{array}$ & OSCE & $\begin{array}{l}\text { Organization for Security and } \\
\text { Co-operation in Europe }\end{array}$ \\
\hline $\mathrm{ECO}$ & $\begin{array}{c}\text { Economic Cooperation } \\
\text { Organization }\end{array}$ & OSPAR & OSPAR Commission \\
\hline ECOSOC & $\begin{array}{c}\text { Economic and Social } \\
\text { Council }\end{array}$ & OTIF & $\begin{array}{c}\text { Intergovernmental } \\
\text { Organisation for } \\
\text { International Carriage } \\
\text { by Rail }\end{array}$ \\
\hline EEA & $\begin{array}{c}\text { European Economic } \\
\text { Area }\end{array}$ & PA & Pacific Alliance \\
\hline EFTA & $\begin{array}{c}\text { European Free Trade } \\
\text { Association }\end{array}$ & SAARC & $\begin{array}{l}\text { South Asian Association for } \\
\text { Regional Cooperation }\end{array}$ \\
\hline ENTENTE & Council of the Entente & SACEP & $\begin{array}{l}\text { South Asia Co-operative } \\
\text { Environment Programme }\end{array}$ \\
\hline $\mathrm{EPO}$ & European Patent Office & SELA & $\begin{array}{l}\text { Latin American and } \\
\text { Caribbean Economic } \\
\text { System }\end{array}$ \\
\hline $\mathrm{ESO}$ & $\begin{array}{l}\text { European Southern } \\
\text { Observatory }\end{array}$ & SICA & $\begin{array}{l}\text { Central American } \\
\text { Integration System }\end{array}$ \\
\hline
\end{tabular}


Table 1. (Continued)

\begin{tabular}{|c|c|c|c|}
\hline abbreviation & long names & abbreviation & long names \\
\hline EU & European Union & SPC & South Pacific Commission \\
\hline EURAMET & $\begin{array}{c}\text { European Association of } \\
\text { National Metrology } \\
\text { Institutes }\end{array}$ & UNASUR & $\begin{array}{c}\text { Union of South American } \\
\text { Nations }\end{array}$ \\
\hline EUROCONTROL & $\begin{array}{c}\text { European Organisation } \\
\text { for the Safety of Air } \\
\text { Navigation }\end{array}$ & UNCTAD & $\begin{array}{l}\text { United Nations Conference } \\
\text { on Trade and Development }\end{array}$ \\
\hline FAO & $\begin{array}{l}\text { Food and Agriculture } \\
\text { Organization of the } \\
\text { United Nations }\end{array}$ & UNDP & $\begin{array}{c}\text { United Nations Development } \\
\text { Programme }\end{array}$ \\
\hline GCC & $\begin{array}{l}\text { Gulf Cooperation } \\
\text { Council }\end{array}$ & UNEP & $\begin{array}{c}\text { United Nations Environment } \\
\text { Programme }\end{array}$ \\
\hline GEF & $\begin{array}{l}\text { Global Environmental } \\
\text { Facility }\end{array}$ & UNESCO & $\begin{array}{c}\text { United Nations Educational, } \\
\text { Scientific and Cultural } \\
\text { Organization }\end{array}$ \\
\hline GUAM & $\begin{array}{l}\text { Organistion for } \\
\text { democracy and } \\
\text { economic } \\
\text { development }\end{array}$ & UNFCCC & $\begin{array}{c}\text { United Nations Framework } \\
\text { Convention or Climate } \\
\text { Change }\end{array}$ \\
\hline HRC & Human Rights Council & UNFPA & $\begin{array}{c}\text { United Nations Population } \\
\text { Fund }\end{array}$ \\
\hline IAEA & $\begin{array}{l}\text { International Atomic } \\
\text { Energy Agency }\end{array}$ & UNGA & $\begin{array}{l}\text { United Nations General } \\
\text { Assembly }\end{array}$ \\
\hline ICAO & $\begin{array}{c}\text { International Civil } \\
\text { Aviation Organization }\end{array}$ & UNHABITAT & $\begin{array}{l}\text { United Nations Human } \\
\text { Settlements Programme }\end{array}$ \\
\hline ICCAT & $\begin{array}{c}\text { Internatonal Commission } \\
\text { for Conservation of } \\
\text { Atlantic Tunas }\end{array}$ & UNHCR & $\begin{array}{c}\text { Office of the United Nations } \\
\text { High Commissioner for } \\
\text { Refugees }\end{array}$ \\
\hline ICCO & $\begin{array}{l}\text { International Cocoa } \\
\text { Organization }\end{array}$ & UNICEF & $\begin{array}{l}\text { United Nations Chidren's } \\
\text { Fund }\end{array}$ \\
\hline ICDO & $\begin{array}{l}\text { International Civil } \\
\text { Defense Organization }\end{array}$ & UNIDO & $\begin{array}{l}\text { United Nations Industrial } \\
\text { Development Organization }\end{array}$ \\
\hline ICES & $\begin{array}{c}\text { International Council } \\
\text { for the Exploration } \\
\text { of the Sea }\end{array}$ & UNSC & $\begin{array}{l}\text { United Nations Security } \\
\text { Council }\end{array}$ \\
\hline $\mathrm{ICO}$ & $\begin{array}{l}\text { International Coffee } \\
\text { Organization }\end{array}$ & UNWOMEN & United Nations Women \\
\hline ICSG & $\begin{array}{l}\text { International Copper } \\
\text { Study Group }\end{array}$ & UNWTO & World Tourism Organization \\
\hline IFAD & $\begin{array}{l}\text { International Fund } \\
\text { for Agricultural } \\
\text { Development }\end{array}$ & UPU & Universa1 Postal Union \\
\hline
\end{tabular}


Table 1. (Continued)

\begin{tabular}{lc|lc}
\hline \hline abbreviation & \multicolumn{1}{c}{ long names } & \multicolumn{1}{c}{ abbreviation } & long names \\
\hline IKSMS & $\begin{array}{c}\text { Internationale Komission } \\
\text { zum Schutz der Mosel }\end{array}$ & WA & Wassenaar Arrangement \\
ILO & $\begin{array}{c}\text { International Labour } \\
\text { Organization }\end{array}$ & WCO & World Customs Organization \\
IMF & $\begin{array}{c}\text { International Monetary } \\
\text { Fund }\end{array}$ & WHO & World Health Organization \\
IMO & $\begin{array}{c}\text { International Maritime } \\
\text { Organization }\end{array}$ & WIPO & World Intellectual Property \\
IMSO & $\begin{array}{c}\text { International Mobile } \\
\text { Satellite Organization }\end{array}$ & WMO & World Meteorological \\
INTERPOL & $\begin{array}{c}\text { Orternational Criminal } \\
\text { Police Organization }\end{array}$ & WTO & World Trade Organization \\
& & & \\
\hline \hline
\end{tabular}

the possibility for states to reintroduce formerly withdrawn proposals or amendments. The decision-making stage encompasses two elements related to the quorum to open decision-taking and high thresholds for decision taking. In addition to the policy cycle, we also coded three institutional design elements on framework conditions, such as whether an IO provides translation, is open to advisors and experts accompanying the diplomats or allows other actors (NGOs etc.) access to the meetings (see Table A1 in the Appendix).

Each of the 34 indicators was formulated as a question (cf. Table A1), which was answered by checking the primary law and rules of procedure of every IO in turn. Since most indicators require to identify the respective context (agenda setting, negotiation, and final decision making as well as framework conditions), we did not compile a list of buzzwords to code in an automated fashion (e.g. with Atlas.ti or MAXQDA) ${ }^{8}$ but hand-coded all materials. In order to achieve inter-coder reliability, all coding decisions were double-checked by a second person.

The DDDI indicators are coded with -1 if they are designed to hinder deliberation between diplomats and with +1 if they are geared towards inducing diplomatic deliberation. For instance, in the agenda-setting stage, deliberation is more likely to take place if the number of IO members who can set the agenda increases. Thus we code the possibility of member states or institutional actors to set the agenda with +1 , whereas in case only specific institutional actor (e.g. chairs or secretariats) can set the agenda, the indicator was coded -1 .

${ }^{8}$ For instance, several of our items relate to the role of chairs, which are called differently in some IOs (e.g. secretary general, president etc.), and they perform sometimes similar tasks concerning the management of debate in different stages of the policy cycle. 
The coding resulted in raw data on the extent to which the 34 indicators are geared to induce or prevent deliberation between diplomats. For the construction of the diplomatic deliberative design index (DDDI), we aggregated the 34 indicators into a total of nine institutional design elements alongside the policy cycle and three additional design items on framework conditions (cf. Table A1). We opted for the aggregation of the indicators into these elements to avoid duplicating similar and logically connected provisions which would have skewed the DDDI. For instance, in the negotiation stage, several indicators relate to the making of proposals. On the one hand, we examine whether proposals could be made by the delegates, but there are also more detailed provisions on the timing, support for, withdrawal and reconsideration of proposals. In general, having the possibility to make proposals, do so without the support of additional states, and the potential to obtain exceptions concerning the timing of proposals can all induce diplomatic deliberations, as it can broaden and expand debates. Yet the latter indicators can logically not exist without the possibility to make proposals in the first place (first indicator). Thus, counting each indicator separately for the DDDI would have inflated the index with respect to this event in the policymaking cycle. Accordingly, we combined all these indicators into one element 'making proposals'. As the subsequent indicators rather qualify the operation of the first (core indicator), the first is weighted higher than the other two. For all such interlinked indicators, we weighted the core indicator by 0.5 and all qualifying indicators taken together are also assigned a weight of 0.5 (cf. Table A1).

We constructed the DDDI by forming the average of the 12 elements (cf. Table A1). For all organisations we did this process for the main legislative body first. For approximately half of the IOs, deliberation does not only take place in the main legislative body, but also in subsidiary bodies such as working groups, committees, specialised commissions etc. For these IOs we additionally applied the coding scheme to the rules of procedure of the subsidiary bodies. We calculated the final DDDI value for these IOs by giving equal weight to the value for the main legislative weight and the average of the values for all subsidiary bodies. As each indicator can take the values of 1 and -1 , the values of the final index are also situated within this range. Thus, an IO's institutional design is most strongly inducing deliberation between diplomats if its DDDI approximates +1 , and most strongly preventing diplomatic deliberation if its DDDI approximates -1 .

\section{A descriptive analysis of the diplomatic deliberative design index}

How do the 114 IOs from our sample score on the diplomatic deliberative design index? When we take a look at the empirical distribution, we 
can see that most IOs seem to induce rather than hamper deliberation. The average value of the DDDI is 0.526 implying that most IOs have more items, which are designed to facilitate deliberation than restrictions of the same. As Figure 1 illustrates the DDDI is almost normally distributed amongst the 114 IOs. Empirically the DDDI ranges between -0.025 and 1 .

Only one organisation is institutionally designed in a manner strongly limiting the exchanges between state delegates: The Latin American Conferencia de Autoridades Audiovisuales y Cinematográficas de Iberoamérica (CAACI) (cf. Table A1, Appendix). Most notably, states are not involved in the agenda setting; it is possible that debates are closed in the negotiation stage without a prior discussion on that decision; and finally in the decision-making stage majority rule applies.

At the other end of the spectrum, the institutional design of the International Commission for the Protection of Mosel and Saar (IKSMS) and the Central American Integration System (SICA) contains only items facilitating deliberation. They both score 1 . The institutional design of IKSMS and SICA both seek to foster deliberation by explicitly allowing for calling of an exceptional meeting in the agenda-setting stage, and both focus on consensus decision-making rules with a one-state one-vote specification in the decision-making stage, and the general IO institutional design allows for the access of non-state and other actors. In addition, IKSMS provides for the translation of documents and speeches.

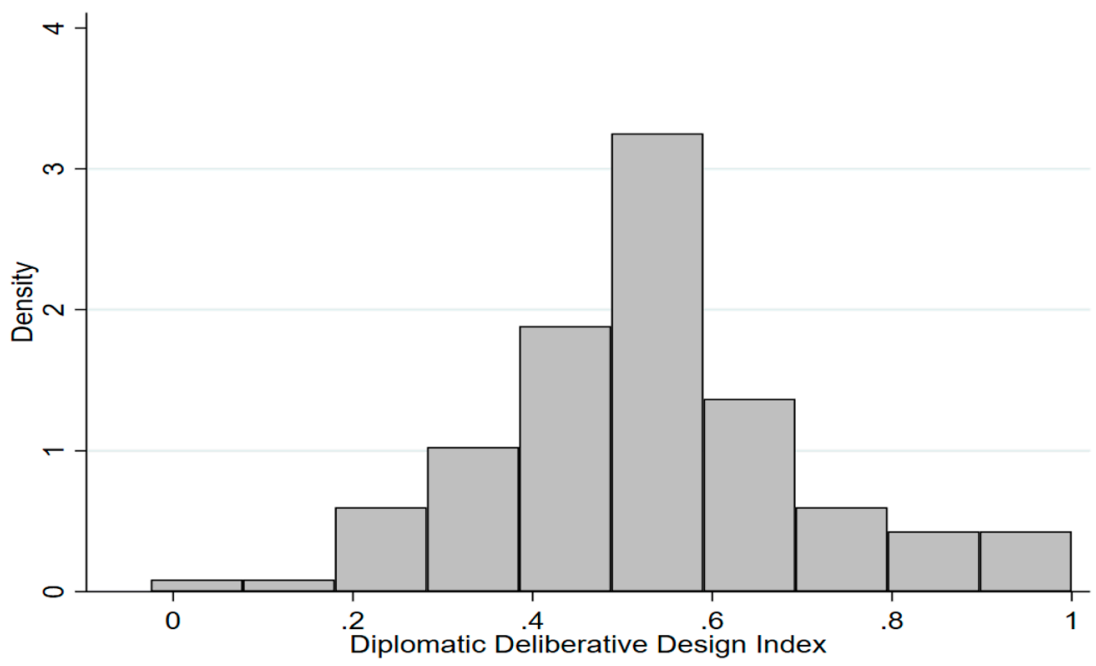

Figure 1: Empirical distribution of the DDDI 
In between are IOs such as the United Nations Security Council (UNSC, 0.557) or the World Trade Organization (WTO, 0.523). For instance, in the UNSC and the WTO states are the agenda setters. In addition, the UNSC and the WTO also fosters deliberation through dynamic debates by allowing states to make proposals and amendments and by giving chairs the competency to accord the right to speak to participants in the negotiation stage; in the decision-making states both IOs include quorums and onestate, one-vote rules. Moreover, the UNSC and the WTO's institutional set-up is designed to allow for transparency of meetings and both have provision that would allow for the access of external actors (but no speaking rights). The UNSC and the WTO also differ in some respects. For instance, only the institutional design of the WTO fosters deliberation by allowing states to flexibly change the agenda and explicitly allow for discussions amongst states to this effect; during the negotiations states have the right of reply and there is a discussion before debates can get closed. In the decision-making stage, consensus rule applies. Also, according to the WTO's general provisions, delegations can bring advisors. In the UNSC, there are likewise institutional design elements allowing for diplomatic deliberation that are not present in the WTO. Most notably, the UNSC fosters deliberation by explicitly allowing for states calling for exceptional meetings in the agenda-setting stage, by flexibly adjusting the order of speakers, by allowing states to make proposals or amendments without secondments in the negotiation stage, and by providing opportunities for reintroducing formerly failed proposals. In general, the UNSC allows for the access of other actors with speaking rights and translations, both of which can also foster deliberation. This illustrates that there is not the one blueprint for the institutional design of IOs when it comes to regulating the extent of diplomatic deliberation. Instead, IOs vary considerably.

\section{Theorising deliberation and IO institutional design choices}

There is a vast literature on the prevalence of deliberation and contestation in democratic states (e.g. Chambers 2003; Fishkin and Luskin 2005; Goodin and Dryzek 2006; Hafer and Landa 2007; Goodin 2008; Thompson 2008; Dryzek 2012), the legal realm (e.g. Alexy 1983; Layman and Saxon 1998; Ferejohn and Pasquino 2002; Zurn 2007; Pickerill 2004; Kim 2009; Lillich and White 1976) or in the societal context (Hajer and Wagenaar 2003; O'Flynn 2006; Ryfe 2007; Schneiderhan and Khan 2008). Amid more recent 'deliberative turn' literature, the scope of actors was further broadened in order to also study deliberation within and between companies and consumers (Doubleday 2004; Palazzo and Scherer 2006; Warner 2008; Guo and Zhang 2012; Singer and Ron 2018), between parliamentarians 
in national legislative arenas (Steiner 2004; Bächtiger et al. 2005; Bara, Weale and Bicquelet 2007; Bächtiger and Hangartner 2010) as well as the role of non-governmental organisations in deliberative processes beyond the nation state (Steenbergen et al. 2003; Nanz and Steffek 2005; Brakman Reiser and Kelly 2011; Niemetz 2014; Tallberg et al. 2013). Moreover, a body of deliberation scholarship evolved which focused on state behaviour on the international level (Johnstone 2003; Naurin 2009; Landwehr and Holzinger 2010; Risse and Kleine 2010; Risse 1999; Risse 2000; Reinhard, Biesenbender and Holzinger 2014; Deitelhoff 2009; Wiener 2014; Müller 2004; Risse 2000). Similar to the first-generation deliberation researchers, deliberative turn scholarship usually draws on case studies of selected interactions or negotiations or uses simulations to empirically examine exchanges between actors (e.g. Nanz and Steffek 2005; Gehring and Kerler 2008; Landwehr and Holzinger 2010; Risse and Kleine 2010; Reinhard, Biesenbender and Holzinger 2014). This body of work illustrates that deliberation is a widespread phenomenon, taking place in the political, societal, legal realms and to some extent also the economic sphere. In addition, deliberation researchers also examine conditions under which deliberation is most likely to unfold. In this regard, deliberation between national diplomats - although the backbone of international relations - and especially the role of different institutional design features that seek to foster diplomatic deliberation in IO agenda-setting, negotiations and decisiontaking, such as rules for speaking rights or the number of interventions allowed, is surprisingly seldom under scrutiny. This is surprising since much of the diplomatic business in IOs is about exchanging claims and simultaneously providing legal, factual, scientific or normative reasons to support one's national position (Johnstone 2003; Müller 2004; Risse 2004). Hence, instead of being empirically rare, diplomatic deliberation is a widespread feature of multilateral negotiations (e.g. Reinhard, Biesenbender and Holzinger 2014; Risse and Kleine 2010; Landwehr and Holzinger 2010; Nanz and Steffek 2005; Gehring and Kerler 2008). Yet, up to now, there are no studies that systematically examine differences in IO institutional diplomatic deliberative design. Thus, there are no specific IO deliberative design theories that this article can draw on. Hence, in order to account for the empirical variation in the IOs' institutional designs, we draw on functionalism, rational design approaches, and liberal approaches and specify hypotheses to account for between-IO variation.

According to functionalism, political systems are designed to perform specified tasks, on the basis of which 'form follows function' (Mitrany 1943; Haas 1964; Gregor 1968). Once actors have identified what a specific political system should do, they select those institutional rules most suited to ensure smooth and effective operation of the system 
(Lowi 1963: 581-2). Thus, IOs' core function is to facilitate state-state cooperation in order to solve real world problems. Accordingly, IO institutional design should ensure that conflicts between state parties can be resolved quickly or circumvented instead of culminating in standstills (Mitrany 1943; Haas 1964). Consequently, functionalism expects a limited number of deliberative elements in IOs in general. This allows states to swiftly address the problems that they have decided to tackle, rather than facing situations in which the development of international rules and norms is highly deliberative but very time-intensive. This general expectation can be qualified in two ways: The more member states an IO has, the more time-intensive negotiations take if all members voice their positions. Thus, functionalism expects that the institutional design of larger IOs delimits diplomatic deliberation more strongly than the institutional design of smaller IOs. The functional operating of IOs can also be influenced by the amount of policy issues on the agenda. IOs with broad policy scopes are responsible for many different topics and are therefore likely to place a high workload on the negotiating actors. Given a broad policy scope and a corresponding high workload, an institutional design with lots of deliberative elements would be dysfunctional, as this would increase the time for decision-making enormously.

Accordingly, bypothesis 1 a states: IOs with a higher number of member states should have fewer deliberative design elements.

Hypothesis $1 b$ focuses on policy aspects: IOs with a broad scope of policy mandates should have fewer deliberative design elements.

On the other hand, swift decision-making is not the only criterion for a rational institutional design of IOs (Goodin 1995; Koremenos, Lipson and Snidal 2001; Panke 2016). States design IOs not only to allow for the efficient making of decisions, but also seek to ensure that the outcomes reflect the normative and legal convictions of the member states and address the underlying problems (Manin 1987; Müller 2004; Schneiderhan and Khan 2008; Risse and Kleine 2010; Eckl 2017). To pursue this aim, institutions include rules fostering diplomatic deliberation. The amount of time an IO allows for deliberation is likely to depend on the nature of the issue at hand and the actors involved in the discussions.

International Organisations can deal with a multitude of issues ranging from highly detailed technical questions to crucial security issues. The saliency of the issue at hand plays an important role: IOs which cover policy areas of high political salience, such as security and economic issues, should generally allow for more deliberation, in order to grant encompassing and sufficient debate of fundamental questions (see further Johnstone 2003). In contrast, IOs which are active in low politics fields should have 
less deliberative institutional designs. Also a second aspect might be of importance: the extent to which IOs might be confronted with internal policy conflicts is likely to vary with the expected heterogeneity of actor interests at stake in the IO (Cox and Jacobson et al. 1973; Hawkins et al. 2006). Within regional IOs it is more likely that problems affect member states in a similar way, which could reduce the number of cleavages the actors have to deal with in the respective IOs. Compared to regional IOs, the actors in global IO come from more diverse contexts. Thus, global IOs might face a higher risk of policy conflicts than regional IOs, and their respective institutional designs should be less deliberative in nature.

Hypothesis 2 a states: IOs' institutional design is more deliberative in nature, if the $\mathrm{IO}$ in question covers high politics.

Hypothesis $2 b$ expects: IOs with a global membership should have fewer deliberative design elements.

In addition to these two theories, we incorporate liberal approaches. Liberal theories open the 'black box' of intra-state decision-making and shed light on how dynamics emanating from the domestic realm can influence state foreign policy preferences and behavioural options (Doyle 1983; Putnam 1988; Moravcsik 1993; Panke and Risse 2007; Panke and Henneberg 2017). Some liberal approaches theorise that socialisation effects take place across levels, according to which domestic modes of actions and experiences can influence the behaviour of actors on the international stage (for an overview Panke and Risse 2007). In democratic countries deliberation is a fundamental part of the political decision-making process (Grigorescu 2015; Biegoń 2016), for instance parliamentarians discuss legislative proposals, political parties engage in controversial discourses etc. In contrast, authoritarian countries often lack a similarly established culture of debate. Following liberal approaches, we would expect that these patterns should be mirrored at the international stage: IOs with a dominantly democratic membership should provide more opportunities for deliberation than IOs which mostly consist of autocratic states.

Grounded on these considerations hypothesis 3 states: IOs with a dominantly democratic membership should be more likely to foster deliberation in their institutional design than IOs with an autocratic membership.

\section{Empirical analysis and discussion of findings}

The following section describes our operationalisation of the independent variables and explains our model specification. On this basis, we put our 
hypotheses to an empirical plausibility probe on the basis of quantitative methods. The diplomatic deliberative design index DDDI captures the extent to which IOs are designed to foster deliberation between diplomats in 2016.

The first independent variable captures the number of member states of an IO (hypothesis 1a). We counted the number of member states with full membership rights in 2016 based on the official IO websites. Associated members, observer states and suspended states were excluded, as these actors do not have the same rights in all IOs (in some IOs observers are by nature silent, in others they may informally speak and in yet others they can take the floor after all full members have spoken). The count variable 'number of member states' is divided by 10, thus a unit change of the variable corresponds to 10 member states the regression table. Hypothesis $1 \mathrm{~b}$ captures the scope of policy competencies of an IO, which we measure through the number of policy fields in which it has a mandate based on its primary law (founding treaty and treaty changes). We coded IO competencies in the following eight fields: economic/finance/labour cooperation; security/ disarmament cooperation; health/safety issues; environment/nature; science/technology/ transport; culture; human rights; other issues. This data has been obtained from the official IO websites. The independent variable of hypothesis 2 a specifies that high politics should lead to a more deliberative institutional design. Out of the policy fields listed above, we constructed a binary variable: the areas of economic/finance/labour cooperation and security/disarmament cooperation were coded as high politics (1) because these fields concern core interests of states. In contrast, the fields of health/safety issues; environment/nature; science/technology/ transport; culture; human rights and other issues were coded as low politics (0). The independent variable of hypothesis $2 \mathrm{~b}$ captures whether an IO is global or regional in nature. Based on the information in the IO treaties, we coded all IOs in which state membership is based on geographical proximity with 0 , whereas all IOs open to countries worldwide were coded with 1 . Hypothesis 3 states that IOs with democratic membership should be more likely to foster deliberation. We calculated the level of democracy within an IO by taking the average of the Polity IV values of the member states for 2016.

Subsequently, we examine the plausibility of the hypotheses with statistical methods. Our dependent variable, the diplomatic deliberative design index (DDDI) is a continuous and approximately normally distributed variable. We use an OLS regression model. The number of observations in our sample is only 114 and thus comparatively low, which requires special caution in model specification and interpretation of the results. Before building the multivariate models, we checked for multicollinearity 
between the independent variables in order to avoid using highly correlated independent variables in the same model. The results of the statistical analysis are shown in Table 2 and support some, but not all theoretical expectations. ${ }^{9}$

A high number of IO member states robustly reduces the deliberativeness of institutional rules (models 1 and 2, Table 2). Thus, there is support for the first functionalist hypothesis, according to which larger IOs with high numbers of member states seek to delimit opportunities for diplomatic deliberation in order to avoid lengthy discussions if all actors would take the floor whenever they have the opportunity to do so and corresponding inefficient IO decision-making. In contrast, smaller IOs with fewer member states can afford highly deliberative institutional designs, as diplomatic deliberation is more likely to be limited in practice if the number of diplomats that can make use of their speaking rights is lower. To illustrate this, the International Atomic Energy Agency (IAEA) as one of the largest organisations with 167 member states has a score of 0.3375 , whereas the comparatively small Eurasian Economic Union (EAEU) ( 5 member states) has a DDDI value of 0.900 .

The second functionalist expectation does not find empirical support: The policy scope of IOs shows a robustly positive effect, but is not

Table 2. Regressions on the DDDI

\begin{tabular}{lcccc}
\hline \hline & model 1 & model 2 & model 3 & model 4 \\
\hline IO size & $-0.005 * *$ & $-0.004 *$ & & \\
& $(0.002)$ & $(0.002)$ & & \\
IO policy scope & 0.002 & & 0.003 & \\
& $(0.009)$ & & $(0.009)$ & \\
high politics & & & $0.079 * *$ \\
& & $(0.031)$ & & $(0.031)$ \\
global IOs & & & $-0.066^{* *}$ & $-0.061 *$ \\
& & & $(0.032)$ & $(0.031)$ \\
democracy & 0.006 & 0.007 & 0.006 & 0.008 \\
& $(0.005)$ & $(0.005)$ & $(0.005)$ & $(0.005)$ \\
Constant & $0.523 * * *$ & $0.475 * *$ & 0 & $0.475^{* * *}$ \\
Observations & $(0.048)$ & $(0.044)$ & $(0.046)$ & $(0.041)$ \\
R-sq & 114 & 114 & 114 & 114 \\
\hline \hline
\end{tabular}

Standard error with *0.10,** $\mathrm{p}<0.05, * * \mathrm{p}<0.01$

9 All findings remain robust and the significance levels do not change, if the models are run for the DDDI excluding the committees, only focusing on the main legislative arena. Also if we include a committee dummy variable in the models reported in Table 2 , the findings remain the same as well. 
significant in any of the models (models 1 and 3 in Table 2). Thus, it is not the case that IOs with a broad policy scope has fewer deliberative design elements. Many different policy mandates do not increase the workload on the IO negotiation table and the corresponding amount of diplomatic deliberation to an extent calling for constitutional limitations of deliberative opportunities. Thus, organisations with equally broad policy coverage such as the OAS (0.568) and the AU (0.245) differ considerably, while IOs specialising in one specific policy area, such as the International Office of Epizootics (OIE, 0.172) or the European Organisation for the Safety of Air Navigation (EUROCONTROL, 0.833) also feature considerably different scores. Taken together, hypothesis $1 \mathrm{~b}$ needs to be rejected.

Hypothesis $2 \mathrm{a}$ is based on rationalist institutionalist design approaches and expects that IOs dealing with the sensitive policy fields of security and economy have many deliberative institutional features. In line with this, Table 2 demonstrates that IOs covering high politics have institutional designs that are more strongly geared towards diplomatic deliberation (models 2 and 4). This suggests that IOs allow for more deliberation and contestation amongst member state diplomats, the more sensitive the issues at stake and in need for broad agreement and legitimacy are. For instance, the CD covers high politics as it is primarily responsible for disarmament and also features a high DDDI (0.929), while the Human Rights Council (HRC) that focusses on human rights scores only with 0.272 . In addition, there is tentative support for hypothesis $2 \mathrm{~b}$. Compared to regional IOs, global IOs seek to foster less diplomatic deliberation. This effect points into the expected direction in models 3 and 4 . To illustrate this point, the institutional designs of regional IOs, such as the Comunidad Andina (CAN) and the European Free Trade Association (EFTA) are highly deliberative in nature, while the designs of many global IOs, such as the United Nations Industrial Development Organization (UNIDO) and the International Criminal Police Organization (INTERPOL), score considerably lower on the DDDI.

Concerning the final strand of literature, liberal theory, Table 2 illustrates that a dominantly democratic membership robustly increases the deliberativeness of an IO, as it is expected by hypothesis 3 . However, the coefficients are not significant in any of the four models so that hypothesis 3 cannot be regarded as being supported by empirical evidence. In line with this, it is not surprising that IOs with identical DDDI scores $(0.536)$ differ considerably with respect to the average regime type of their member states, the OECD (9.088) and the GCC $(-8.833)$. 


\section{Conclusions}

Among other questions, political philosophy, in general, and global constitutionalism, in particular, explores what constitutes a good political order. While the former's predominant focus has been on how to design a legitimate state in order to express values such as equality, freedom, justice, sovereignty or security (e.g. Hobbes 1668; Rousseau 1920; Locke and Laslett 1988; Tully and Skinner 1993; Kraut 2002), from early on some philosophers of the state were also interested in what constitutes a good international order (most prominently Kant 1795). In this context, political philosophers, political scientists and legal scholars examined authority beyond the nation state as well as legitimacy, justice, and fairness of global governance. ${ }^{10}$ Not least since the number of IOs and the body of international law has considerably increased since the end of WWII, ${ }^{11}$ institutional design scholarship evolved that examines the set-up of international organisations. ${ }^{12}$

For instance, IO institutional design scholarship has studied the extent of legalisation of IOs. ${ }^{13}$ This strand of research illustrates that formal institutional design of IOs influences state conduct, such as (non-)compliance, and points out that this has important implications for the prospects and effectiveness of cooperation beyond the nation state. ${ }^{14}$ Another strand of IO institutional design research focuses on the openness of IO for non-state actors (Tallberg et al. 2013). Most importantly, IO openness brings about promises for democratic global governance, although biased transnational access leads to an unequal representation of civil society interests in global governance arrangements (Tallberg et al. 2013). A third prominent IO institutional design approach examines how and why IOs differ with respect to the pooling and delegation of authority (Hooghe and Marks 2015; Hooghe et al. 2017). This strand of institutional design scholarship sheds light on how IO set-up influences dynamics and outcomes of governance beyond the nation state (Hooghe and Marks 2015; Hooghe et al. 2017). Despite the current trend towards studying IO institutional design, not all

10 e.g. Kumm 2004; Zürn 2004; Buchanan and Keohane 2006; March and Olsen 1998; Barnett and Duvall 2004; Bernstein 2011; Mac Amhlaigh 2016.

11 cf. Hoffmann 1956; Haas 1964; Kratochwil and Ruggie 1986; Abbott and Snidal 1998; Barnett and Finnemore 1999; Alvarez 2005; Hurd 2011; Hooghe and Marks 2015.

12 Dryzek 1987; Goodin 1995; Pierson 2000; Koremenos, Lipson and Snidal 2001; Tallberg et al. 2013; Hooghe and Marks 2015.

13 e.g. Abbott et al. 2000; Abbott and Snidal 2000; Goldstein et al. 2000; Kahler 2000; Kirton and Trebilcock 2004; Alvarez 2005; Alter 2014.

14 Fisher 1981; Chayes and Handler-Chayes 1993; Mitchell 1994; Mitchell 1996; Simmons 1998; Checkel 1999; Joerges 2000; Raustiala and Slaughter 2002; Tallberg 2002; Alter 2003; Schimmelfennig, Engert and Knobel 2003; Falkner et al. 2004; Langlois and Langlois 2004; Zürn and Joerges 2005. 
features of potential importance for international negotiation dynamics and outcomes have already been under scrutiny. Although deliberation between state actors in IOs forms the core of global governance, ${ }^{15}$ we know little about whether IOs differ in the extent to which they foster diplomatic deliberation. This is important since IOs - similar to states - need to balance two competing aims: On the one hand, they need to institutionally allow for swift policy-cycles, in which the actors can set the agenda, negotiate and pass outcomes in a time-efficient manner. On the other hand, they need to provide room for deliberation between actors in order to allow for policy outcomes that have a more realistic chance of being passed and been complied with. While the first aim suggests that institutional designs delimit opportunities for deliberation between actors, the second aim requires that institutional designs allow for diplomatic deliberation. In order to learn more about whether and how IOs balance these competing objectives, this article sheds light on the institutional design of IOs with respect to agenda setting, negotiation, and the decisiontaking stage, and examines which institutional design features seek to foster deliberation between diplomats. In addition, this article examines why IOs' institutional designs vary in the extent to which they seek to foster diplomatic deliberation.

The answers to the research question, 'To what extent do IOs incorporate deliberative institutional design features and how can we explain variation in the extent to which institutional design seeks to foster diplomatic deliberation between IOs?' are twofold. First, IOs considerably differ in the extent to which they are designed to induce diplomatic deliberation. While only one IO places much emphasis on swift policy-cycles and delimits diplomatic deliberation strongly (CAACI), other IOs made a different choice with respect to the two competing aims: Most notably, the institutional designs of IKSMS and SICA place strong emphasis on diplomatic deliberation and achieve the highest possible score on the DDDI. Most IOs balance both aims: speedy IO decision-making and room for diplomatic deliberation in the IO policy-cycle. For instance, IOs such as OECD, OAS and WTO, achieve median values on the DDDI. These findings suggest that it has not only been the case in the domestic arena that founding fathers drafted constitutions and wrote rules of procedures of parliamentary assemblies in a manner purposefully providing room for deliberation between the constituent actors whilst also ensuring that too much deliberation does not lead to a standstill (Bächtiger et al. 2005), but that similar consideration were also likely to be at play for the architects of today's IOs.

15 Barnett and Duvall 2004; Holzinger 2004; Müller 2004; Nanz and Steffek 2004; Deitelhoff and Müller 2005; Panke 2010; Zürn 2012. 
Second, variation in the extent to which IOs are institutionally designed to foster deliberation cannot be accounted for by a single theoretical approach. Instead, a combination of functionalist and rational institutional design hypotheses account for variation in the extent to which IOs are designed to bring about diplomatic deliberation. By contrast, we do not find evidence for the theoretical expectation derived from liberal approaches. Our analysis revealed that three factors impact IOs' DDDI scores. IOs are significantly more deliberative in their design, if they cover high politics, are smaller in size and are regional in character.

Our analysis in this article focuses on formal rules inhibiting and fostering deliberation between state actors in IOs. This is important because institutional designs are constitutive to interaction as they provide the formal rules not only of who is a member, who sets the agenda, who is how involved in the negotiations and how decisions are passed, but also on which topics decisions can be taken in the first place. Yet, neoinstitutionalism suggests that institutional designs guide but do not determine actor behaviour (March and Olsen 1984; Powell and DiMaggio 1991; Hall and Taylor 1996). Thus, is could well be the case that in IOs which place great emphasis on speeding up decision-making by delimiting deliberative institutional design elements, such as the CAACI, actors engage in practice in more deliberation than the institutional design alone would lead us to expect. It would be beyond the scope of this contribution to examine theoretically and empirically how institutional rules are used in practice and whether and under what conditions diplomats create functional equivalents (e.g. deliberating in coffee breaks or alternative venues) in case IO designs strongly delimit deliberation in the main arena. Yet, studying the nexus between institutional design and actor practices is a fruitful field for future research in IOs as well as in institutions on the domestic level.

Taken together, there is not a 'one size fits all' approach when it comes to designing IOs. IOs have not all subscribed to the same choice on how strongly they seek to induce or prevent deliberation between diplomats. Which real-world effects variation in the extent to which IOs foster diplomatic deliberation brings about remains largely to be seen.

State of the art domestic-level deliberation research suggests that deliberation makes a difference (e.g. Carpini, Cook and Jacobs 2004; Bächtiger et al. 2005; Manin 1987): while it reduces the speed of decision-making, it has positive implications for the problem-solving effectiveness and legitimacy of political systems in the domestic realm.

The same might also apply to the international realm. IOs with strongly deliberative institutional design are likely to induce diplomatic deliberation. While the exchange of principled positions and reasons between the actors can require considerable time and slow down the effectiveness of passing 
IO outcome documents - especially if IOs are large in size - deliberation can also have positive effects at the same time. Diplomatic deliberation can be conducive to IO decisions beyond the lowest common denominator since final outcomes are grounded in sound reasons (Eckl 2017). Ideally, diplomatic deliberation brings about outcomes in the interest of all stakeholders rather than outcomes that reflect the relative bargaining power of a few great players. If outcomes rest on the agreement of all actors, public accountability of IO decisions is likely to increase, as all member states are collectively responsible for the outcomes. High-quality outcomes have further positive ramifications as they can generate legitimacy for the IO concerned (Anderson, Bernauer and Kachi forthcoming), which in turn is also important to address the democratic deficit problem of today's global governance (Tallberg and Zürn forthcoming). In short, with respect to IOs designed to foster deliberation we do expect a trade-off between a more limited speed of decision-making on the one hand, and high-quality outcomes as well as legitimacy on the other hand for governance beyond the nation state as well.

\section{Acknowledgements}

This article is part of a research project funded by the German Research Council (DFG), grant number PA 1257/5-1. We presented earlier versions of the article at the ISA conference 2018 and at the DreiLänder-Tagung 2019 and are grateful for the constructive and lively discussions. In particular, we would like to thank Loriana Crasnic, Thomas Doerfler, James Hollway, Nilgün Önder, and Patrick Theiner. This article benefitted from the research assistance of Sarah Bordt, Chiara Fury, Lea Gerhard, Pauline Grimmer, Nicolas Koch, Sebastian Lehmler, Laura Lepsy, Laura Maghetiu, Fabiola Mieth, Leonardo Rey, Laurenz Schöffler, Jannik Schulz, Leylan Sida, Edward Vaughan and Philipp Wagenhals, who helped with collecting the primary law sources and the rules of procedures, coding the IO institutional designs, and supporting us in compiling the database.

\section{References}

Abbott, Kenneth W and David Gartner. 2012. "Reimagining Participation in International Institutions." Journal of International Law and International Relations 8(1):1-35.

Abbott, Kenneth W, Robert O Keohane, Andrew Moravcsik, Anne-Marie Slaughter and Snidal Duncan. 2000. "The Concept of Legalization.” International Organization 54(3):401-19.

Abbott, Kenneth W and Snidal Duncan. 1998. "Why States Act through Formal International Organizations." Journal of Conflict Resolution 42(1):3-32. 
Abbott, Kenneth W and Snidal Duncan. 2000. "Hard and Soft Law in International Governance." International Organization 54(3):421-56.

Alexy, Robert. 1983. Theorie der juristischen Argumentation. Die Theorie des rationalen Diskurses als Theorie der juristischen Begründung. Frankfurt: Suhrkamp.

Alter, Karen. 2003. "Do International Courts Enhance Compliance with International Law?" 25 Review of Asian and Pacific Studies 51-78.

Alter, Karen. 2014. New Terrain of International Law: Courts, Politics, Rights. Princeton, NJ: Princeton University Press.

Alvarez, José E. 2005. International Organizations as Law-Makers. Oxford: Oxford University Press.

Anderson, Brilé, Thomas Bernauer and Aya Kachi (forthcoming). "Does International Pooling of Authority Affect the Perceived Legitimacy of Global Governance?" Review of International Organizations.

Bächtiger, André and Dominik Hangartner. 2010. "When Deliberative Theory Meets Empirical Political Science: Theoretical and Methodological Challenges in Political Deliberation.” Political Studies 58(4):609-29.

Bächtiger, André and John Parkinson. 2019. Mapping and Measuring Deliberation: Towards a New Deliberative Quality. Oxford: Oxford University Press.

Bächtiger, André, Markus Spörndli, Marco R Steenbergen and Jürg Steiner. 2005. "The Deliberative Dimensions of Legislatures." Acta Politica 40(2):225-38.

Bara, Judith, Albert Weale and Aude Bicquelet. 2007. "Analysing Parliamentary Debate with Computer Assistance.” Swiss Political Science Review 13(4):577-605.

Barnett, Michael N and Raymond Duvall, 2004. Power in Global Governance. Cambridge: Cambridge University Press.

Barnett, Michael N and Martha Finnemore. 1999. "The Politics. Power and Pathologies of International Organizations.” International Organization 53(4):699-732.

Beaulac, Stéphane. 2004. The Power of Language in the Making of International Law: The Word Sovereignty in Bodin and Vattel and the Myth of Westphalia. Leiden: Martinus Nijhoff Publishers.

Bernstein, Steven. 2011. "Legitimacy in Intergovernmental and Non-State Global Governance." Review of International Political Economy 18(1):17-51.

Bexell, Magdalena, Jonas Tallberg and Anders Uhlin. 2010. "Democracy in Global Governance: The Promises and Pitfalls of Transnational Actors." Global Governance: A Review of Multilateralism and International Organizations 16(1):81-101.

Biegoń, Dominika. 2016. Hegemonies of Legitimation. New York, NY: Springer

Brakman Reiser, Dana and Claire Kelly. 2011. "Linking NGO Accountability and the Legitimacy of Global Governance.” Brooklyn Journal of International Law 36(4):1011-73.

Buchanan, Allen and Robert O Keohane. 2006. "The Legitimacy of Global Governance Institutions." Ethics \& International Affairs 20(4):405-37.

Carpini, Michael X Delli, Fay Lomax Cook and Lawrence R Jacobs. 2004. "Public Deliberation, Discursive Participation, and Citizen Engagement: A Review of the Empirical Literature." Annual Review of Political Science 7:315-44.

Chayes, Abram and Antonia Handler-Chayes. 1993. "On Compliance." International Organization 47(2): 175-205.

Chambers, Simone. 2003. "Deliberative Democratic Theory." Annual Review of Political Science 6(1):307-326.

Checkel, Jeffrey T. 1999. "Compliance and Conditionality." ARENA Working Papers WP 00/181-34.

Cohen, Joshua. 2003. "Deliberation and Democratic Legitimacy" In Debates in Contemporary Political Philosophy, edited by Derek Matravers and Jon Pike, 342-61. London: Routledge. 
Cohen, Jean L. 2012. Globalization and Sovereignty: Rethinking Legality, Legitimacy, and Constitutionalism. Cambridge: Cambridge University Press.

Cox, Robert W and Harold K Jacobson et al. 1973. The Anatomy of Influence: Decision Making in International Organizations. New Haven, CT: Yale University Press.

Deitelhoff, Nicole. 2006. Überzengung in der Politik. Grundzüge einer Diskurstheorie internationalen Regierens. Frankfurt: Suhrkamp.

Deitelhoff, Nicole. 2009. "The Discursive Process of Legalization: Charting Islands of Persuasion in the ICC Case." International Organization 63(1):33-65.

Deitelhoff, Nicole and Harald Müller. 2005. "Theoretical Paradise - Empirically Lost? Arguing with Habermas." Review of International Studies 31(1):167-79.

Dingwerth, Klaus, Antonia Witt, Ina Lehmann, Ellen Reichel and Tobias Weise. 2019. "International Organizations under Pressure. Introduction.” In International Organizations under Pressure: Legitimating Global Governance in Challenging Times, edited by Klaus Dingwerth, Antonia Witt, Ina Lehmann, Ellen Reichel and Tobias Weise, 1-28. Oxford: Oxford University Press.

Doubleday, Robert. 2004. "Institutionalising Non-governmental Organisation Dialogue at Unilever: Framing the Public as 'Consumer-Citizens'." Science and Public Policy 31(2):117-26.

Doyle, Michael. 1983. "Kant, Liberal Legacies, and Foreign Affairs." Philosophy and Public Affairs 12(3/4):205-35.

Dryzek, John S. 1987. "Discursive Designs: Critical Theory and Political Institutions." American Journal of Political Science 31(3):656-79.

Dryzek, John S. 2000. Deliberative Democracy and Beyond: Liberals, Critics, Contestations. Oxford: Oxford University Press.

Dryzek, John S. 2012. Foundations and Frontiers of Deliberative Governance. Oxford: Oxford University Press.

Dunoff, Jeffrey L. 2006. "Constitutional Conceits: The WTO's 'Constitution' and the Discipline of International Law." European Journal of International Law 17(3):647-75.

Dunoff, Jeffrey L and Joel P Trachtman. 2009. Ruling the World? Constitutionalism, International Law, and Global Governance. Cambridge: Cambridge University Press.

Eckl, Julian. 2017. "Successful Governance Reform and Its Consequences: How the Historical Drive for Shorter Meetings and More Time Efficiency Reverberates in Contemporary World Health Assemblies." Global Health Governance 11(1):40-56.

Falkner, Gerda, Miriam Hartlapp, Simone Leiber and Oliver Treib. 2004. "Non-Compliance with EU Directives in the Member States: Opposition through the Backdoor?" West European Politics 27(3):452-73.

Ferejohn, John and Pasquale Pasquino. 2002. "Constitutional Courts as Deliberative Institutions: Toward an Institutional Theory of Constitutional Justice." In Constitutional Justice, East and West, edited by Wojciech Sadurski, 21-36. The Hague: Kluwer Law International.

Fisher, Roger. 1981. Improving Compliance with International Law. Charlottesville, VA: University of Virginia Press.

Fishkin, James S. 2002."Deliberative Democracy." In The Blackwell Guide to Social and Political Philosophy, edited by Robert L. Simon, 221. Malden: Blackwell Publishers.

Fishkin, James S and Robert C Luskin. 2005. "Experimenting with a Democratic Ideal: Deliberative Polling and Public Opinion" Acta Politica 40(3):284-98.

Franck, Thomas M. 1990. The Power of Legitimacy among Nations. Oxford: Oxford University Press.

Gehring, Thomas and Michael Kerler. 2008. "Institutional Stimulation of Deliberative DecisionMaking: Division of Labour, Deliberative Legitimacy and Technical Regulation in the European Single Market.” Journal of Common Market Studies 46(5):1001-23. 
Goldstein, Judith, Miles Kahler, Robert O Keohane and Anne-Marie Slaughter. 2000. "Introduction: Legalization and World Politics." International Organization 54(3):385-99.

Goodin, Robert E. 1995. The Theory of Institutional Design. Cambridge: Cambridge University Press.

Goodin, Robert E. 2008. Innovating Democracy: Democratic Theory and Practice after the Deliberative Turn. Oxford: Oxford University Press.

Goodin, Robert E and John S Dryzek. 2006. "Deliberative Impacts: The Macro-Political Uptake of Mini-Publics.” Politics \& Society 34(2):219-44.

Gray, Julia. 2018. "Life, Death, or Zombie? The Vitality of International Organizations." International Studies Quarterly 62(1):1-13.

Gregor, James A. 1968. "Political Science and the Use of Functional Analysis." The American Political Science Review 62(2):425-39.

Grigorescu, Alexandru. 2015. Democratic Intergovernmental Organizations? Normative Pressures and Decision-Making Rules. Cambridge: Cambridge University Press.

Guo, Liang and Juanjuan Zhang. 2012. "Consumer Deliberation and Product Line Design." Marketing Science 31(6):995-1007.

Gutmann, Amy and Dennis Thompson. 2009. Why Deliberative Democracy? Princeton, NJ: Princeton University Press.

Haas, Ernst B. 1964. Beyond the Nation-State: Functionalism and International Organization. Stanford, CA: Stanford University Press.

Habermas, Jürgen. 1995a. Theorie des Kommunikativen Handelns. Band 1 Handlungsrationalität und gesellschaftliche Rationalisierung. Frankfurt am Main: Suhrkamp.

Habermas, Jürgen. 1995b. Theorie des Kommunikativen Handelns. Band 2 zur Kritik der funktionalistischen Vernunft. Frankfurt am Main: Suhrkamp.

Hafer, Catherine and Dimitri Landa. 2007. "Deliberation as Self-Discovery and Institutions for Political Speech." Journal of Theoretical Politics 19(3):29-60.

Hajer, Maarten A and Hendrik Wagenaar. 2003. Deliberative Policy Analysis: Understanding Governance in the Network Society. Cambridge: Cambridge University Press.

Hall, Peter A and Rosemary C R Taylor. 1996. "Political Science and the Three New Institutionalisms." Political Studies XLIV(5):936-57.

Hamlin, Alan and Philip Pettit. 1989. The Good Polity: Normative Analysis of the State. Oxford: Blackwell.

Hawkins, Darren G, David A Lake, Daniel L Nielson and Michael J Tierney. 2006. "Delegation under Anarchy: States, International Organizations, and Principal-Agent Theory." In Delegation and Agency in International Organizations, edited by Darren G Hawkins, David A Lake, Daniel L Nielson and Michael J Tierney, 3-37 Cambridge: Cambridge University Press.

Hobbes, Thomas. 1668. Leviathan. London: Hackett Publishing.

Hoffmann, Stanley. 1956. "The Role of International Organization: Limits and Possibilities." International Organization 10(3):357-72.

Holzinger, Katharina. 2004. "Bargaining through Arguing: An Empirical Analysis Based on Speech Act Theory." Political Communication 21(2):195-222.

Hooghe, Liesbet and Gary Marks. 2015. "Delegation and Pooling in International Organizations." Review of International Organizations 10(3):305-28.

Hooghe, Liesbet, Gary Marks, Tobias Lenz, Jeanine Bezuijen, Besir Ceka and Svet Derderyan. 2017. Measuring International Authority: A Postfunctionalist Theory of Governance, Volume III. Oxford: Oxford University Press.

Hurd, Ian. 2011. International Organizations: Politics, Law, Practice. Cambridge: Cambridge University Press.

Joerges, Christian. 2000. "Compliance Research in Legal Perspective." Manuscript. 
Joerges, Christian and Jürgen Neyer. 1997. "From Intergovernmental Bargaining to Deliberative Political Processes: The Constitutionalisation of Comitology." European Law Journal 3(3):73-99.

Johnstone, Ian. 2003. "Security Council Deliberations: The Power of the Better Argument." European Journal of International Law 14(3):437-80.

Kahler, Miles. 2000. "Conclusion: The Causes and Consequences of Legalization." International Organization 54(3):661-83.

Kant, Immanuel. 1795. "Perpetual Peace. A Philosophical Sketch.” In On History, edited by Lewis White Beck. New York, NY: Macmillan

Kelsen, Hans. 1966. Principles of International Law. New York, NY: Rinehart \& Co.

Kim, Pauline T. 2009. "Deliberation and Strategy on the United States Courts of Appeals: An Empirical Exploration of Panel Effects." University of Pennsylvania Law Review 157:1319-81.

Kirton, John J and Michael J Trebilcock. 2004. Hard Choices, Soft Law: Voluntary Standards in Global Trade, Environment, and Social Governance. Aldershot: Ashgate.

Koremenos, Barbara, Charles Lipson and Snidal Duncan. 2001. "The Rational Design of International Institutions." International Organization 55(4):761-99.

Koskenniemi, Martti. 2006. From Apology to Utopia: The Structure of International Legal Argument. Cambridge: Cambridge University Press.

Kratochwil, Friedrich. 1989. Rules, Norms, and Decisions. On the Conditions or Practical and Legal Reasoning in International Relations and Domestic Affairs. Cambridge and New York, NY: Cambridge University Press.

Kratochwil, Friedrich and John Gerard Ruggie. 1986. "International Organization: A State of the Art on an Art of the State." International Organization 40(4):753-75.

Kraut, Richard. 2002. Aristotle: Political Philosophy. Oxford: Oxford University Press.

Kumm, Mattias. 2004. "The Legitimacy of International Law: A Constitutionalist Framework of Analysis." European Journal of International Law 15(5):907-31.

Kuyper, Jonathan. 2014. "The Democratic Potential of Systemic Pluralism." Global Constitutionalism 3(2):170-99.

Landwehr, Claudia and Katharina Holzinger. 2010. "Institutional Determinants of Deliberative Interaction." European Political Science Review 2(3):373-400.

Langlois, Jean-Pierre P and Catherine Langlois. 2004. "Provisions for Noncompliance and Treaty Value: A Game Theoretic Perspective.” International Studies Quarterly 48(2): 383-408.

Layman, Allen and Charles Saxon. 1998. "The Legal Argument Game of Legal Relations.” Murdoch University Electronic Journal of Law 5(3):24.

Lenz, Tobias and Lora Anne Viola. 2017. "Legitimacy and Institutional Change in International Organisations: A Cognitive Approach.” Review of International Studies 43(5):939-61.

Levi, Edward Hirsch. 2013. An Introduction to Legal Reasoning, Chicago, IL: University of Chicago Press.

Lillich, Richard B and G Edward White. 1976. "The Deliberative Process of the International Court of Justice: A Preliminary Critique and some Possible Reforms.” American Journal of International Law 28-40.

Locke, John and Peter Laslett. 1988. Locke: Two Treatises of Government-Student Edition. Cambridge: Cambridge University Press.

Lowi, Theodore J. 1963. “Toward Functionalism in Political Science: The Case of Innnovation in Party Systems." The American Political Science Review 57(3):570-83.

Mac Amhlaigh, Cormac. 2016. "Harmonising Global Constitutionalism." Global Constitutionalism 5(2):173-206.

Manin, Bernard. 1987. “On Legitimacy and Political Deliberation.” Political Theory 15(3):338-68. 
Mansbridge, Jane. 2015. “A Minimalist Definition of Deliberation.” In Deliberation and Development: Rethinking the Role of Voice and Collective Action in Unequal Societies, edited by Patrik Heller and Vijayendra Rao, 27-50. Washington DC: International Bank for Development and Reconstruction.

March, James G and Johan P Olsen. 1984. "The New Institutionalism: Organizational Factors in Political Life." American Political Science Review (78):734-49.

March, James G and Johan P Olsen. 1998. "The Institutional Dynamics of International Political Orders." International Organization 52(4):943-69.

Menkel-Meadow, Carrie. 1983. "Legal Negotiation: A Study of Strategies in Search of a Theory." Law \& Social Inquiry 8(4):905-37.

Mitchell, Ronald B. 1994. "Regime Design Matters: Intentional Oil Pollution and Treaty Compliance." International Organization 48(3):425-58.

Mitchell, Ronald B. 1996. "Compliance Theory: An Overview." In Improving Compliance with International Environmental Law, edited by James Cameron, Jacob Werksman and Peter Roderick, 3-28. London: Earthscan.

Mitrany, David. 1943. A Working Peace System: An Argument for the Functional Development of International Organization. London: Royal Institute of International Affairs.

Moravcsik, Andrew. 1993. "Preferences and Power in the European Community: A Liberal Intergovernmental Approach." Journal of Common Market Studies 31(4):473-524.

Müller, Harald. 2004. "Arguing, Bargaining and All That. Reflections on the Relationship of Communicative Action and Rationalist Theory in Analysing International Negotiations." European Journal of International Relations 10(3):395-435.

Nanz, Patrizia and Jens Steffek. 2004. "Global Governance, Participation and the Public Sphere." Government and Opposition 39(2):314-35.

Nanz, Patrizia and Jens Steffek. 2005. "Assessing the Democratic Quality of Deliberation in International Governance: Criteria and Research Strategies." Acta Politica 40(3):368-83.

Naurin, Daniel. 2009. "Most Common When Least Important: Deliberation in the European Union Council of Ministers." British Journal of Political Science 40(1):31-50.

Niemetz, Martin Daniel. 2014. "Empowering Civil Society: How to Increase the Input of NGOs into Security Council Deliberation." Journal of Human Rights Practice 6(1):69-88.

O'Flynn, Ian. 2006. Deliberative Democracy and Divided Societies. Edinburgh: Edinburgh University Press.

Palazzo, Guido and Andreas Georg Scherer. 2006. "Corporate Legitimacy as Deliberation: A Communicative Framework." Journal of Business Ethics 66(1):71-88.

Panke, Diana. 2006. "More Arguing Than Bargaining? The Institutional Designs of the European Convention and Intergovernmental Conferences Compared." Journal of European Integration 28(4):357-79.

Panke, Diana. 2010. "Why Discourse Matters Only Sometimes: Effective Arguing beyond the Nation-State." Review of International Studies 36(1):145-68.

Panke, Diana. 2013. "Getting Ready to Negotiate in International Organizations? On the Importance of the Domestic Construction of National Positions." Journal of International Organizations Studies 4(2):25-38.

Panke, Diana. 2016. "Living in an Imperfect World? Incomplete Contracting \& the Rational Design of International Organizations." Journal of International Organizations Studies $7(1): 25-38$.

Panke, Diana and Ingo Henneberg. 2017. International Organizations and Foreign Policy. Oxford: Oxford University Press.

Panke, Diana and Thomas Risse. 2007. "Liberalism." In International Relations Theories: Descipline and Diversity, edited by Tim Dunne, Milja Kurki and Steve Smith, 89-108. Oxford: Oxford University Press. 
Pevehouse, Jon C, Timothy Nordstrom and Kevin Warnke. 2004. "The COW-2 International Organizations Dataset Version 2.0." Conflict Management and Peace Science 21(2):101-19.

Pickerill, J Mitchell. 2004. Constitutional Deliberation in Congress: The Impact of Judicial Review in a Separated System. Durham. NC: Duke University Press.

Pierson, Paul. 2000. "The Limits of Design: Explaining Institutional Origins and Change." Governance: An International Journal of Policy and Administration 13(4):475-799.

Powell, Walter W and Paul J DiMaggio. 1991. The New Institutionalism in Organizational Analysis. Chicago, IL: University of Chicago Press.

Putnam, Robert. 1988. "Diplomacy and Domestic Politics. The Logic of Two-Level Games." International Organization 42(2):427-60.

Raustiala, Kal and Anne-Marie Slaughter. 2002. "International Law, International Relations and Compliance." In Handbook of International Relations, edited by Carlsnaes Walter, Thomas Risse and Beth A. Simmons, 538-58. London: Sage Publications.

Reinhard, Janine, Jan Biesenbender and Katharina Holzinger. 2014. "Do Arguments Matter? Argumentation and Negotiation Success at the 1997 Amsterdam Intergovernmental Conference." European Political Science Review 6(2):283-307.

Risse, Thomas. 1999. "International Norms and Domestic Change: Arguing and Communicative Behavior in the Human Rights Area." Politics and Society 27(4):529-59.

Risse, Thomas. 2000. “'Let's Argue!': Communicative Action in World Politics.” International Organization 54(1):1-39.

Risse, Thomas. 2004. "Global Governance and Communicative Action." Government and Opposition 39(2):288-313.

Risse, Thomas and Mareike Kleine. 2010. "Deliberation in Negotiations.” Journal of European Public Policy 17(5):708-26.

Rousseau, Jean-Jacques. 1920. The Social Contract, \& Discourses, London: JM Dent \& Sons, Ltd. Ryfe, David M. 2007. "Toward a Sociology of Deliberation." Journal of Public Deliberation $3(1): 1-27$.

Schimmelfennig, Frank, Stefan Engert and Heiko Knobel. 2003. "Costs, Commitment and Compliance: The Impact of EU Democratic Conditionality on Latvia, Slovakia and Turkey." Journal of Common Market Studies 41(3):495-518.

Schneiderhan, Erik and Shamus Khan. 2008. "Reasons and Inclusion: The Foundation of Deliberation." Sociological Theory 26(1):1-24.

Shapiro, Ian. 2003. The State of Democratic Theory. Princeton, NJ: Princeton University Press.

Simmons, Beth A. 1998. "Compliance with International Agreements." The Annual Review of Political Science 175-93.

Singer, Abraham and Ron Amit. 2018. "Models of Shareholder Democracy: A Transnational Approach." Global Constitutionalism 7(3):422-46.

Steenbergen, Marco R, André Bächtiger, Markus Spörndli and Jürg Steiner. 2003. "Measuring Political Deliberation: A Discourse Quality Index." Comparative European Politics $1(1): 21-48$.

Steffek, Jens. 2000. "The Power of Rational Discourse and the Legitimacy of International Governance.” EUI Working Paper No. 2000/46 Florence.

Steiner, Jürg. 2004. Deliberative Politics in Action: Analysing Parliamentary Discourse. Cambridge: Cambridge University Press.

Tallberg, Jonas. 2002. "Paths to Compliance: Enforcement, Management, and the European Union.” International Organization 56(3):609-43.

Tallberg, Jonas, Thomas Sommerer, Theresa Squatrito and Christer Jönsson. 2013. The Opening up of International Organizations: Transnational Access in Global Governance. Cambridge: Cambridge University Press. 
Tallberg, Jonas and Michael Zürn. "The Legitimacy and Legitimation of International Organizations: Introduction and Framework." Review of International Organizations (forthcoming).

Thompson, Dennis F. 2008. "Deliberative Democratic Theory and Empirical Political Science." Annual Review of Political Science 11:497-520.

Tully, James and Quentin Skinner. 1993. An Approach to Political Philosophy: Locke in Contexts. Cambridge: Cambridge University Press.

Warner, Mildred E. 2008. "Reversing Privatization, Rebalancing Government Reform: Markets, Deliberation and Planning." Policy and Society 27(2):163-74.

Wiener, Antje. 2014. A Theory of Contestation. New York, NY: Springer.

Zurn, Christopher F. 2007. Deliberative Democracy and the Institutions of Judicial Review. Cambridge: Cambridge University Press.

Zürn, Michael. 2004. "Global Governance and Legitimacy Problems." Government and Opposition 39(2):260-87.

Zürn, Michael. 2012. "Global Governance as Multi-Level Governance.” In Oxford Handbook of Governance, edited by David Levi-Faur, 730-44. Oxford and New York, NY: Oxford University Press.

Zürn, Michael and Christian Joerges. 2005. Law and Governance in Postnational Europe: Compliance beyond the Nation-State. Cambridge: Cambridge University Press. 


\section{Appendix}

Table A1. Coding scheme diplomatic deliberative design elements of IOs

\begin{tabular}{|c|c|c|c|}
\hline component & element & indicator & weights \\
\hline \multirow[t]{6}{*}{ agenda setting } & call meetings & $\begin{array}{l}\text { it is possible to call exceptional } \\
\text { meetings (yes } 1, \text { no }-1 \text { ) }\end{array}$ & 1 \\
\hline & prepare agenda & $\begin{array}{l}\text { member states can participate in } \\
\text { agenda setting (yes } 1, \text { no }-1 \text { ) }\end{array}$ & 1 \\
\hline & $\begin{array}{l}\text { change agenda } \\
\text { in meeting }\end{array}$ & $\begin{array}{l}\text { it is possible to change the agenda once } \\
\text { a meeting has started (yes } 1, \text { no }-1 \text { ) }\end{array}$ & 0,5 \\
\hline & & $\begin{array}{l}\text { there is a discussion on the agenda } \\
\text { (yes } 1, \text { no-1) }\end{array}$ & 0,25 \\
\hline & & $\begin{array}{l}\text { there are time limits on discussion } \\
\text { of the agenda (yes }-1 \text {, no } 1 \text { ) }\end{array}$ & 0,125 \\
\hline & & $\begin{array}{l}\text { there is a limit on the number of } \\
\text { speakers (yes }-1 \text {, no } 1 \text { ) }\end{array}$ & 0,125 \\
\hline \multirow[t]{9}{*}{ negotiation } & $\begin{array}{c}\text { dynamics of } \\
\text { debate }\end{array}$ & $\begin{array}{l}\text { there are explicit provisions for a } \\
\text { dynamic debate (yes } 1, \text { no }-1 \text { ) }\end{array}$ & 0,5 \\
\hline & & $\begin{array}{l}\text { exceptions to order of speakers are } \\
\text { possible (e.g. some speakers have } \\
\text { precedence or speakers can give } \\
\text { way) (yes } 1, \text { no }-1 \text { ) }\end{array}$ & 0,25 \\
\hline & & $\begin{array}{l}\text { Chair has the right to accord the } \\
\text { right to speak to participants } \\
\text { (yes } 1, \text { no }-1 \text { ) }\end{array}$ & 0,125 \\
\hline & & $\begin{array}{l}\text { delegates have a right of reply, } \\
\text { irrespective whether the list } \\
\text { of speakers is already closed } \\
\text { (yes } 1, \text { no }-1 \text { ) }\end{array}$ & 0,125 \\
\hline & $\begin{array}{l}\text { Chair compe- } \\
\text { tences to } \\
\text { regulate }\end{array}$ & $\begin{array}{l}\text { Chair has competencies to regulate/ } \\
\text { restrict debate (yes } 1, \text { no }-1 \text { ) }\end{array}$ & 0,5 \\
\hline & & $\begin{array}{l}\text { Chair has the right to shorten } \\
\text { the speeches of participants } \\
\text { (yes }-1 \text {, no } 1 \text { ) }\end{array}$ & 0,125 \\
\hline & & $\begin{array}{l}\text { it is possible to set time limits } \\
\text { on speeches of participants } \\
\text { (yes }-1, \text { no } 1 \text { ) }\end{array}$ & 0,125 \\
\hline & & $\begin{array}{l}\text { it is possible to limit the number } \\
\text { of times one and the same } \\
\text { delegate can give a speech on } \\
\text { an agenda item (yes }-1, \text { no } 1 \text { ) }\end{array}$ & 0,125 \\
\hline & & $\begin{array}{l}\text { Chair can close list of speakers } \\
\text { during an ongoing debate } \\
\text { (yes }-1, \text { no } 1 \text { ) }\end{array}$ & 0,125 \\
\hline
\end{tabular}


Table A1. (Continued)

\begin{tabular}{|c|c|c|c|}
\hline component & element & indicator & weights \\
\hline & \multirow[t]{6}{*}{ making proposals } & $\begin{array}{l}\text { it is possible to make proposals/ } \\
\text { amendments (yes } 1 \text {, no }-1 \text { ) }\end{array}$ & 0,5 \\
\hline & & $\begin{array}{l}\text { a single state can make proposals/ } \\
\text { amendments (yes } 1, \text { no }-1 \text { ) }\end{array}$ & 0,1 \\
\hline & & $\begin{array}{l}\text { it is possible to make exceptions } \\
\text { concerning the timing of } \\
\text { proposals (yes } 1, \text { no }-1 \text { ) }\end{array}$ & 0,1 \\
\hline & & $\begin{array}{l}\text { proposals/amendments can be } \\
\text { withdrawn (yes }-1 \text {, no } 1)\end{array}$ & 0,1 \\
\hline & & $\begin{array}{l}\text { withdrawn proposals can be } \\
\text { reintroduced by other states } \\
\text { (yes } 1, \text { no }-1 \text { ) }\end{array}$ & 0,1 \\
\hline & & $\begin{array}{l}\text { it is possible to reconsider rejected/ } \\
\text { adopted proposals (yes } 1, \text { no }-1 \text { ) }\end{array}$ & 0,1 \\
\hline & \multirow[t]{5}{*}{$\begin{array}{l}\text { interrupt } \\
\text { discussion }\end{array}$} & $\begin{array}{l}\text { it is possible to interrupt the } \\
\text { discussions (yes }-1 \text {, no } 1 \text { ) }\end{array}$ & 0,5 \\
\hline & & $\begin{array}{l}\text { it is possible to close the debate } \\
\text { on a specific item (yes }-1, \text { no } 1)\end{array}$ & 0,125 \\
\hline & & $\begin{array}{l}\text { a discussion is required before } \\
\text { closing the debate on an item } \\
\text { (yes } 1, \text { no }-1 \text { ) }\end{array}$ & 0,125 \\
\hline & & $\begin{array}{l}\text { it is possible to close the meeting } \\
\text { (yes }-1 \text {, no } 1 \text { ) }\end{array}$ & 0,125 \\
\hline & & $\begin{array}{l}\text { a discussion is required before } \\
\text { closing the meeting (yes } 1 \text {, no }-1 \text { ) }\end{array}$ & 0,125 \\
\hline \multirow[t]{3}{*}{ decision-making } & quorum & $\begin{array}{l}\text { there is a required quorum for } \\
\text { taking decisions (yes } 1, \text { no }-1 \text { ) }\end{array}$ & 1 \\
\hline & voting & $\begin{array}{l}\text { consensus / unanimity is required } \\
\text { to take decisions (yes } 1, \text { no }-1 \text { ) }\end{array}$ & 0,75 \\
\hline & & one state one vote (yes 1, no -1 ) & 0,25 \\
\hline \multirow[t]{5}{*}{$\begin{array}{l}\text { framework } \\
\text { conditions }\end{array}$} & transparency & $\begin{array}{l}\text { it is possible to make initial public } \\
\text { meetings private (or the other } \\
\text { way round) according to the } \\
\text { delegates wishes (yes } 1 \text {, no }-1 \text { ) }\end{array}$ & 1 \\
\hline & \multirow[t]{2}{*}{ external support } & $\begin{array}{l}\text { delegations can bring advisors/ } \\
\text { experts (yes } 1 \text {, no }-1 \text { ) }\end{array}$ & 0,5 \\
\hline & & $\begin{array}{l}\text { translation is organized by } \mathrm{IO} \\
\quad(\text { yes } 1, \text { no }-1)\end{array}$ & 0,5 \\
\hline & \multirow[t]{2}{*}{ external actors } & $\begin{array}{l}\text { other actors (NGOs, other IOs, } \\
\text { observers etc. ) have access } \\
\text { to meetings (yes } 1, \text { no }-1 \text { ) }\end{array}$ & 0,5 \\
\hline & & $\begin{array}{l}\text { other actors can voice their opinion } \\
\text { in meetings (yes } 1, \text { no }-1 \text { ) }\end{array}$ & 0,5 \\
\hline
\end{tabular}


Table A2. DDDI scores

\begin{tabular}{|c|c|c|c|c|c|c|c|}
\hline IO & DDDI & IO & DDDI & IO & DDDI & IO & DDDI \\
\hline $\mathrm{AC}$ & 0.482 & EEA & 0.6302 & IOM & 0.475 & $\mathrm{PA}$ & 0.600 \\
\hline ACS & 0.511 & EFTA & 0.7500 & IOOC & 0.453 & SAARC & 0.563 \\
\hline ACTO & 0.547 & ENTENTE & 0.5175 & IORA & 0.623 & SACEP & 0.594 \\
\hline AFRICARICE & 0.571 & EPO & 0.7143 & ISA & 0.463 & SELA & 0.619 \\
\hline $\mathrm{AL}$ & 0.481 & ESO & 0.3254 & ITSO & 0.300 & SICA & 1.000 \\
\hline ALADI & 0.538 & EU & 0.3393 & ITTO & 0.595 & SPC & 0.339 \\
\hline ANRPC & 0.5 & EURAMET & 0.7500 & ITU & 0.377 & UNASUR & 0.875 \\
\hline $\mathrm{APT}$ & 0.568 & EUROCONTROL & 0.8333 & IWC & 0.805 & UNCTAD & 0.506 \\
\hline ARIPO & 0.219 & FAO & 0.7096 & MRC & 0.536 & UNDP & 0.542 \\
\hline $\mathrm{AU}$ & 0.245 & GCC & 0.5361 & NAFO & 0.400 & UNEP & 0.525 \\
\hline BENELUX & 0.578 & GEF & 0.6071 & NASCO & 0.441 & UNESCO & 0.489 \\
\hline BIPM & 0.396 & GUAM & 0.4792 & NC & 0.597 & UNFCCC & 0.605 \\
\hline BSEC & 0.807 & HRC & 0.2716 & NEAFC & 0.657 & UNFPA & 0.542 \\
\hline CAACI & -0.025 & IAEA & 0.3375 & NPFC & 0.520 & UNGA & 0.413 \\
\hline CABI & 0.667 & $\mathrm{ICAO}$ & 0.6656 & OAPEC & 0.530 & UNHABITAT & 0.525 \\
\hline CAN & 0.893 & ICCAT & 0.3333 & OAS & 0.568 & UNHCR & 0.427 \\
\hline CARICOM & 0.435 & ICCO & 0.3146 & OECD & 0.536 & UNICEF & 0.504 \\
\hline CCNR & 0.736 & ICDO & 0.4125 & OEI & 0.625 & UNIDO & 0.187 \\
\hline $\mathrm{CD}$ & 0.929 & ICES & 0.5833 & OIC & 0.500 & UNSC & 0.557 \\
\hline CEFTA & 0.906 & ICO & 0.5727 & OIE & 0.172 & UNWOMEN & 0.597 \\
\hline CENSAD & 0.466 & ICSG & 0.7344 & OIF & 0.333 & UNWTO & 0.507 \\
\hline CERN & 0.333 & IFAD & 0.4521 & OIV & 0.236 & UPOV & 0.427 \\
\hline CLAC & 0.233 & IKSMS & 1.0000 & OLADE & 0.513 & UPU & 0.381 \\
\hline $\mathrm{CoE}$ & 0.696 & ILO & 0.4523 & OPANAL & 0.436 & WCO & 0.513 \\
\hline COSAVE & 0.500 & IMF & 0.5625 & OPCW & 0.608 & WHO & 0.452 \\
\hline DANUBE & 0.589 & IMO & 0.5458 & OSCE & 0.279 & WIPO & 0.527 \\
\hline EAEU & 0.900 & IMSO & 0.4646 & OSPAR & 0.569 & WMO & 0.427 \\
\hline ECO & 0.589 & INTERPOL & 0.3023 & OTIF & 0.563 & WTO & 0.523 \\
\hline ECOSOC & 0.425 & IOC & 0.6023 & & & & \\
\hline
\end{tabular}

Table A3. Summary statistics independent variables

\begin{tabular}{lccccc}
\hline \hline Variable & Observations & Mean & Standard deviation & Minimum & Maximum \\
\hline global IO & 114 & 0.5 & 0.502 & 0 & 1 \\
IO policy scope & 114 & 2.509 & 1.806 & 1 & 7 \\
power asymmetry & 114 & 27.504 & 1.374 & 22.484 & 29.590 \\
high politics & 114 & 0.526 & 0.502 & 0 & 1 \\
democratic member states & 114 & 5.435 & 3.149 & -8.833 & 10 \\
\hline \hline
\end{tabular}

